\title{
Characterization of Ajaokuta Coke for Blast Furnace
}

\section{Ironmaking}

\author{
${ }^{1 *}$ A.O. Adeleke, ${ }^{2}$ R.S. Makan, and ${ }^{1}$ S.A. Ibitoye \\ 1.Department of Materials Science and Engineering,Faculty of Technology, \\ Obafemi Awolowo University, Ile-Ife, Osun State, Nigeria. \\ 2.National Metallurgical Development Centre (NMDC), P.M.B. 2116, \\ Jos, Plateau State. Nigeria \\ *Corresponding Author: Email: aoadeleke2002@yahoo.com
}

\begin{abstract}
The $300 \mathrm{~kg}$ coke sample received from Ajaokuta Steel Plant was subjected to proximate analysis and pilot scale size distribution test. The proximate analysis showed that the coke contains $0.38 \%, 13.45 \%, 2.72 \%$ and $0.14 \%$ of moisture, ash, volatile matter and sulphur respectively; while size distribution test gave micum 10 and micum 40 of 3.62\% and 89.67\% respectively. Therefore, the coke satisfies the blast furnace requirements for moisture, sulphur and micum strength. However, its ash and volatile contents exceed the specified limits except for Indian standard practice.
\end{abstract}

Keywords: Coke, proximate analysis, size distribution, micum strength

\section{INTRODUCTION}

Coals are organic detrital sedimentary rocks that originate from a variety of plant material and different tissues deposited in more or less aquatic locations. The evolution of vegetable matter to coal begins by degradation of the former by bacterial activity under the action of 
temperature and pressure over a long period of time[1]. Coke is the residue obtained when coal is heated to high temperatures in the absence of air. This process is called carbonization or destructive distillation of coal. Types of coke include metallurgical coke, foundry coke, formed coke, coke for electric furnaces and coke for resistor in graphitization furnaces. Metallurgical grade coke is produced by carbonizing bituminous coals at temperatures above $1,100^{\circ} \mathrm{C}$ and they satisfy the chemicals, physical and mechanical requirements for use in the blast furnace ironmaking process. For the blast furnace operation, coke is charged along with sinter, the iron bearing material and limestone, the fluxing agent. In addition to its role as an energy source, metallurgical coke supports the overlying furnace burden and provides the permeability necessary for the high efficiency of the blast furnace [2].

In order to perform the aforementioned functions, the coke must have good strength so that it does not disintegrate during its descent through the blast furnace shaft. Additionally, some elements like sulphur present in coke adversely affect the quality of iron metal produced. A number of tests have been developed for the quantitative assessment of the properties of coke which influence the operation of the blast furnace. These tests include proximate analysis, sulphur content determination and physical characterization of coke to determine the micum indices. Proximate analysis involves determination for moisture, ash, volatile matter and fixed carbon of coke.

Micum index indicates the strength of coke against both impact and abrasion. The micum drum is made of mild steel and is $1 \mathrm{~m}$ in internal diameter. $50 \mathrm{~kg}$ sample of coke above $63 \mathrm{~mm}$ size is rotated for 4 minutes at the rate of 25 revolutions/min. After rotation, the coke is taken out and screened through standard round holes. The percentage coke retained on 40mm and that passing through 10mm screens are designated as M40 and M10 indices respectively. The 
former indicates the resistance of the coke to breakage by impact and the latter by abrasion[3]. For the blast furnace operation at the Ajaokuta Steel Plant, the coke characteristics requirements are as follows [4].

Ash content (db) - max. 1.2\%

Volatile matter (daf) - max. 2.0\%

International Standard Organization (ISO) M40 - min. 78\%

ISO M10 - max. 9\%

Moisture $-1 \%$ maximum if dry quenched and $4 \%$, maximum if wet quenched.

On completion of its first phase, the integrated steel plant at Ajaokuta will require 1.3 million tons of coke to produce 1.3 million tons of liquid iron [5]. The total world consumption of coke for 1990 was put at 376 million tons. The specific coke consumption per ton of hot metal for 1990 was 6.25 ton, 5.61 ton and 4.8 ton for France, Germany and Japan respectively [6].

\section{MATERIALS AND METHODS}

\section{Materials}

About 300kg of coke was received from the Ajaokuta Steel Plant (ASP) for pilot scale characterization at the National Metallurgical Development Centre (NMDC), Jos.

\section{Methods}

250g sample of the coke was subjected to coke stabilization, size distribution and micum drum tests to determine the micum indices that indicate the mechanical strength of the coke for blast furnace ironmaking. The proximate analysis of the sample was also carried out. The experimental procedures involved are outlined as follows: 


\section{Proximate Analysis}

Proximate analysis involves determination for moisture, volatile matter, ash and fixed carbon. Samples ground and screened to pass 250 microns were used to determine each parameter.

\section{Moisture}

The silica crucible was preheated at $110^{\circ} \mathrm{C}$ for 1 hour and allowed to cool to room temperature. One gramme of coke sample was then heated for 1hour. The loss in weight accounts for the moisture content $\mathrm{f}$ the coke.

\section{Volatile matter}

The standard silica crucible was preheated in a muffle furnace at $900^{\circ} \mathrm{C}$ for 7 minutes. One gramme of coke was then heated in the silica crucible at $900^{\circ} \mathrm{C}$ for 7 minutes. The loss in weight gives the volatile matter.

\section{Ash content determination}

The standard silica crucible was preheated in the muffle furnace at $825^{\circ} \mathrm{C}$ for 1 hour. It was then cooled in the desiccators and weighed. One gramme coke sample was now placed in the crucible and heated at $825^{\circ} \mathrm{C}$ for 1 hour with the lid on. The crucible and its content was then cooled in the desiccators and weighed. The weight of the incombustible residue accounts for ash content.

\section{Fixed Carbon}

The fixed carbon for the coke was determined by calculation with the relation:

Fixed carbon $=100-$ moisture $\%$ - ash $\%$ - volatile matter $\%$

The results of proximate analysis are presented in Table 1. 
Table 1: Proximate Analysis of Ajaokuta Coke Sample

\begin{tabular}{lll}
\hline S/No & Parameters & Value (\%) \\
\hline 1. & Moisture & 0.38 \\
2. & Ash (nd) & 13.45 \\
3. & Ash (db) & 13.50 \\
4. & Volatile matter (ad) & 2.34 \\
5. & Volatile matter (db) & 2.35 \\
6. & Volatile matter (daf) & 2.72 \\
7. & Fixed Carbon (ad) & 84.15 \\
8. & Fixed Carbon (daf) & 97.66 \\
9. & Sulphur (ad) & 0.14 \\
10. & Sulphur (db) & 0.14 \\
\hline
\end{tabular}

Note: ad - as determined, $\mathrm{db}$ - dried basis, daf - dried ash free

\section{Determination of total sulphur in coke by Eschka method}

The method involves igniting $1 \mathrm{~g}$ of coke sample and Eschka mixture (2 parts of magnesium oxide with 1 part anhydrous sodium carbonate). The sulphur is dissolved in water and then precipitated as barium sulphate. The precipitate is then filtered, ashed and weighed. The experimental procedure is as follows: One gramme of coke sample was weighed into a 30ml porcelain crucible and mixed with $3 g$ of Eschka mixture. The blank and the standard sample were prepared in a similar manner. The crucibles were then placed in a cold muffle furnace and gradually heated to $800^{\circ} \mathrm{C}$ for about 60 minutes. The temperature was maintained for an additional 60 minutes. The crucibles were removed, slightly cooled and stirred to ensure that no black coke particles occur. The crucibles were them emptied into $400 \mathrm{ml}$ beakers containing 100mls of hot water. Digestion was done for 45 minutes, with occasional stirring. The solution in each beaker was now decanted through 540 filter paper into a $400 \mathrm{ml}$ beaker. 
The insoluble material in the first beaker was thoroughly washed with hot water. After washing in this manner, the solid was transferred to the filter paper and washed 5 times with hot water. The filtrate volume was about $250 \mathrm{ml}$. The residue was then discarded. Three drops of methyl orange indicator was added. Sodium hydroxide was then added drop wise until just neutral.

Then, $1 \mathrm{ml}$ of hydrochloric acid was added to just acid and $25 \mathrm{ml}$ of potassium sulphate was also added using an 'A' grade pipette. The sample was now heated to boiling and 10mls of barium chloride solution was slowly added with stirring. The solution was maintained near boiling for 30 minutes and then stood overnight. The solution was then filtered with No 42 paper and washed well with hot water. The wet filter paper was placed into a crucible and ignited for 15 minutes. The paper was gradually smoked off in the muffle furnace, avoiding burning. The temperature was then gradually raised to $800^{\circ} \mathrm{C}$ and maintained for 1 hour. The crucible was cooled and barium sulphate weighted. Total sulphur is calculated as follows:

$$
\text { Total sulphur \% }=(\mathrm{A}-\mathrm{B}) / \mathrm{C} \quad \mathrm{x} 13.74
$$

Where $\quad \mathrm{A}=$ mass of barium sulphate from sample

$$
\begin{aligned}
& \mathrm{B}=\text { mass of barium sulphate from blank } \\
& \mathrm{C}=\text { mass of sample used }
\end{aligned}
$$

The results of sulphur analysis by Eschka method is shown in Table 1.

\section{Determination of micum indices}

The determination of micum indices involves coke stabilization, coke screening and micum drum test. Coke stabilization involves dropping $250 \mathrm{~kg}$ of coke from a height of $5.0 \mathrm{~m}$ into a 
receiver once. In coke screening, the stabilized coke was screened through screens of round holes sizes $<10,10-20,20-40,40-60,60-80$ and $>80 \mathrm{~mm}$. For micum drum test, $50 \mathrm{~kg}$ of the coke screened in the coke screening stage not passing a round hole sieve of modulus 48 (63mm) was rotated 25 revolutions/min for 4 minutes and then subjected to coke screening again. The micum 10 (M10) was determined as the percentage of the coke residue below 10mm size, while micum 40 (M40) was the percentage of the residue above $40 \mathrm{~mm}$ sieve size. The results obtained in size distribution test is shown in Table 2 and the micum indices in Table 3.

Table 2: Size Distribution of Ajaokuta Coke

\begin{tabular}{lll}
\hline S/No & Sieve Size & \% Distribution \\
\hline 1. & $-10 \mathrm{~mm}$ & 2.81 \\
2. & $10-20 \mathrm{~mm}$ & 1.93 \\
3. & $20-40 \mathrm{~mm}$ & 15.54 \\
4. & $40-60 \mathrm{~mm}$ & 30.92 \\
5. & $60-80 \mathrm{~mm}$ & 26.85 \\
6. & $+80 \mathrm{~mm}$ & 21.96 \\
\hline
\end{tabular}

Table 3: Micum drum Indices of Ajaokuta Coke

\begin{tabular}{|l|l|}
\hline Micum Drum Indices & Results \\
\hline M10 & $3.62 \%$ \\
\hline M40 & 89.67 \\
\hline
\end{tabular}




\section{DISCUSSION OF RESULTS}

The moisture content of $0.38 \%$ for the coke falls within the range required for the operation of the Ajaokuta Steel Plant blast furnace [4]. The moisture content is also far lower than 2.52\%, and 4.6\% reported for Usinor and Ijmuiden coke plants respectively [7,8]. However the ash content of $13.45 \%$ exceeds the limit required for Ajaokuta, and also far exceeds the 9.7\% reported for both Ijmuiden and Usinor coke plants and 13.35\% for China coke with titanoferrous magnetite addition [9]. However, the ash content of $13.45 \%$ determined is far lower than 24\%, for typical Indian coke [3].

The ash in coke is of great significance in the blast furnace operation. High ash lowers the carbon content and requires the use of more limestone as fluxes and thus the use of more energy for slagging. This results in increased coke rate and lower efficiency of the metallurgical process. It has been reported that $1 \%$ increase in ash causes an increase of 1.5$2 \%$ in coke rate, $1.5 \%$ in flux rate and lower blast furnace efficiency by 3-5\%[3].

The volatile matter of $2.72 \%$ determined for the coke exceeds the limit of $2.0 \%$ set for the coke to be used in Ajaokuta. The sulphur content of $0.14 \%$ meets the requirement for Ajaokuta and is lower than $0.61 \%$ and $0.83-0.91 \%$ determined for Indian and German coke respectively $[3,10]$. The sulphur content is also lower than $0.48 \%$ reported for Chinese coke [8]. It is also lower than $0.55-0.60 \%$ in coke for efficient, high productivity blast furnace in United Kingdom [11]. Sulphur in iron can exist either as iron sulphide (FeS) or manganese sulphide (MnS). The ferrous sulphide forms brittle, low melting point, yellowish brown films round the solid steel crystals and causes the metal to split when forged. It also tends to promote the formation of cementite and thus a harder iron [12]. The micum indices of M10 of $3.62 \%$ and M40 at $89.67 \%$ satisfy the requirements for blast furnace operations at 
Ajaokuta. The M40 value is better than $73-76.41 \%$ determined for coke produced by stamped charging in Germany [13]. The M40 of $84-89 \%$ for some Japanese coke are also lower than for the Ajaokuta coke [11]. The M10 of 5.6-6.2\% and 5.5-7.0\% determined respectively for the German and Japanese coke show that the the two coke have lower abrasion resistance in comparison to the Ajaokuta coke.

\section{CONCLUSION}

The coke supplied to the Ajaokuta Steel Plant has been shown to partially meet the basic chemical, physical and mechanical characteristics required of coke for blast furnace ironmaking. The micum indices, M10 and M40 values of 3.62\% and $89.67 \%$ meet the requirement for resistance to abrasion and fragmentation respectively, while the sulphur content of $0.14 \%$ is far lower than the upper limit of $0.9 \%$ for metallurgical coke. However, the ash and volatile contents exceed the specified limits except for Indian standard practice.

\section{ACKNOWLEDGEMENT}

The authors hereby gratefully acknowledge the experimental contributions of Messer Agabi and Sani, both of Coke Oven pilot plant (COPP), National Metallurgical Development Centre, Jos.

\section{REFERENCES}

[1] Loison, R., Foch, P. and Boyer, A., 1989, Coke quality and production, Butterworth, London. 
[2] National Metallurgical Development Centre (NMDC) manual for pilot scale coke over plant, 1994, Jos, Nigeria.

[3] Moitra, A.K., Banerjee, N.G. Shrinkhande, K.Y., Sing, K. Raja, K. and Banerjee, S (1992): Studies on coal carbonization in India, Central Fuel Research Institute (CFRI) publication, Calcutta.

[4] Federal Ministry of Mines, Power and Steel circular, 1992, on Carbonization tests for Ajaokuta coke requirements, Lagos, Nigeria.

[5] Task force, 1987, on the maximum utilization of Nigerian coals at the Ajaokuta Steel Plant, Lagos, Nigeria.

[6] Anderson, D.F., 1992, “Trends in demand for and supply of coal and coke”, $2^{\text {nd }}$ international cokemaking congress, London, pp. 9.

[7] Garin, J., Pol, F. and Poulet, Ph., 1987, "Coal selection and blending practice at the USINOR coke oven plant”, $1^{\text {st }}$ international cokemaking congress, Essen, section III. 2.

[8] Brouwer, R. C., Schoone, E.E. and Toxopeus, H.L., 1992, “Coal Injection driven to the limits”, Iron and Steel Engineer, Vol. 69, No 12, pp. 22.

[9] Zhan, X. and Xu, C., 1987, “The behaviour of coke by use of titaniferrous magnetite in blast furnace', $1^{\text {st }}$ international cokemaking congress, Essen, $\quad$ Section 12.

[10] Weskamp, W., Rhode, W., Stewen, E., and Habermehl, D., 1987, “Greater coke strength through reactive additives to coking blends”, $1^{\text {st }}$ International Cokemaking Congress, Essen, Section III. I.

[11] Willmers R.R. and Bennington, C.R., 1992, “Coke quality requirements for efficient, high productivity blast furnace operation at high coal injection rates”, $\quad 2^{\text {nd }}$ international coke making congress, London, pp. 275. 
[12] Rollason, E.C., 1973, Metallurgy for Engineers, The English Language Book Society and Edward Arnold Publisher.

[13] Echterhoff, J., Killich, H.J. and Frick, H., 1992, "Production of blast furnace coke by stamp charging and utilization of recycled coke breeze”, $2^{\text {nd }}$ international cokemaking congress, London, pp. 188. 